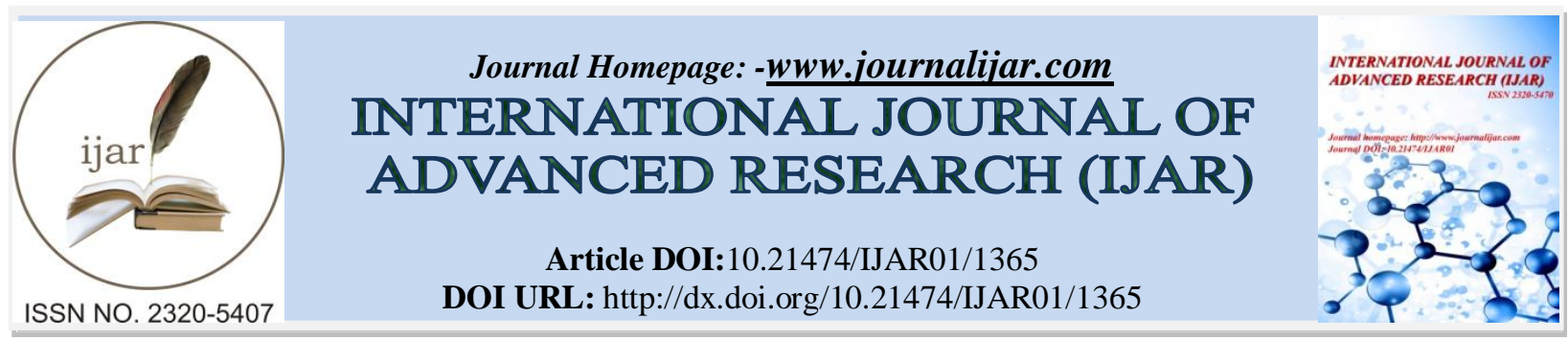

RESEARCH ARTICLE

\title{
EVALUATION OF PROTECTIVE AND THERAPEUTIC POTENTIAL OF CURCUMIN ON CADMIUM CHLORIDE INDUCED RESPIRATORY TOXICITY IN SWISS ALBINO MICE (MUS MUSCULUS) ON THE BASIS OF HISTOPATHOLOGICAL, HISTOENZYMOLOGICAL AND BIOCHEMICAL ASSESSMENT.
}

Preeti Singh and Sweety Gupta.

Cytogenetic \& Endocrinology Research laboratory, Department of Zoology, College of Science, Mohan LalSukhadia University, Udaipur Rajasthan, 313001, India.

\section{Manuscript Info}

\section{Manuscript History}

Received: 18 June 2016

Final Accepted: 19 July 2016

Published: August 2016

Key words:-

Curcumin, cadmium chloride, toxicity, lactate dehydrogenase, lung.

\section{Abstract}

Curcumin derived from turmeric has been attributed with immense potential to combat innumerable ailments, especially inflammation related disorders. In contrast to the beneficial effects of curcumin cadmium an omnipresent transitional element, is a known environmental toxicant of twentieth century. Hence the aim of the present study was to evaluate the protective and therapeutic potential of curcumin on cadmium chloride induced respiratory toxicity in Swiss Albino Mice (Musmusculus) on the basis of histopathological, histoenzymological and biochemical assessment. The study constituted of three experimental groups, each comprising of six mice viz. Control group- administered only vehicle; (a) experimental group administered curcumin (10mg/animal/day); (b) experimental group administered cadmium chloride $(50 \mathrm{mg} / \mathrm{kg} / \mathrm{animal} / \mathrm{day})$ and (c) experimental group administered curcumin $(10 \mathrm{mg} / \mathrm{animal} /$ day $)$ for 15 days and on the 16th day administered cadmium chloride $(50 \mathrm{mg} / \mathrm{kg} / \mathrm{animal} /$ day). As compared to control group, lungs of only cadmium treated mice showed altered histopathological profile, as manifested by thickening of interalveolar septa, aggregation of lymphocyte infiltration etc. These cadmium treated mice assessed for lactate dehydrogenase by biochemical and histoenzymological means showed significant elevated distribution pattern. In experimental group pretreated with curcumin did not reveal such acute histopathological deterioration and in the histochemical profile the assessed biochemical levels were similar to that of control.

Copy Right, IJAR, 2016,. All rights reserved.

\section{Introduction:-}

Curcumin is a polyphenol herbal remedy obtained from the rhizome of dietary spice turmeric, commonly used as a yellow coloring and flavoring agent in food. It is biologically active, non - toxic chemical that has been used as a protective and therapeutic agent since ancient times in treatment of various aliments viz. wound healing, bruises, insect bites, jaundice, diabetic wounds, asthma, fever, cold, cough, blood purifier, in skin disease and hepatic disorders etc. (Soni and Kuttan 1992; Venkatesanet al.1997; Asai and Miyazawa 2001; Shahedet al. 2001 and

Corresponding Author:-Preeti Singh. 
Phanet al. 2001; Zhang et al.2013).It has been reported to exert diverse antioxidant, anti-inflammatory and anticancer properties (Aggarwal and shishodia 2006; Sharma et al. 2005; Singh and Khar 2006). Various reports are present related to its pharmacokinetics actions (Pandey et al. 2010; Singh et al. 2007; 2010(4); 2011; 2012; Naksuriya et al 2014). In the contemporary scenario increasing environmental pollutants are causing severe threats to human lives. Cadmium, being one such omnipresent environmental pollutant, a known carcinogen, mutagen and a clastogen, plays no beneficial role in human biological system (ATSDR 2012; Xu et al. 2015). In mammal 30\% to $60 \%$ of cadmium is absorbed by lungs and $1 \%$ to $10 \%$ through contaminated food and water by small intestine (Nordberg and Kjellström1979). Its multifaceted toxicity leads to oxidative imbalance, resulting in stress, induction of cell proliferation, attainment of apoptosis resistance, resulting in malignancy (Hess et al. 1958; ATSDR 2012). Since cigratte smoking induced cadmium toxicity has been shown to result in acute inflammation of lungs and resultant physiological malfunction, not much information has been generated showing the injurious effects of orally ingested cadmium on pulmonary toxicity and protection rendered by curcumin against such toxicity. Hence in the present research work an effort has been made to show the beneficial potential of curcumin against toxicity rendered by orally ingested cadmium.

\section{Materials and methods:-}

\section{Chemicals:-}

Cadmium chloride (Molecular weight $=201.32$ ) was obtained from Glaxo company (India). Curcumin was purchased from Loba Chem. Pvt. Ltd. All the other chemicals and solvents used were of analytical grade.

\section{Animals and treatment:-}

The study was conducted on adult Swiss albino mice 32-50 days old and weighing around to 30-40g which were maintained in plastic cages under controlled light conditions (12:12 light: dark cycle), relative humidity (50 $\pm 5 \%$ ) and temperature $\left(37 \pm 2^{\circ} \mathrm{C}\right)$, fed with mice feed and given ad libitum access to water.

\section{Experimental design:-}

The experimental protocol constituted of threeexperimentalgroups each,consisting of six mice. The dose of cadmium chloride was prepared fresh in distilled water and $(0.2 \mathrm{ml})$ was administered by gastric gavages route. Curcumin was administered along with food pellets.

In the parallel control groups mice were administered only vehicle (distilled water).

Group experimental group 1- Mice were administered curcumin (10mg/animal/day).

Group experimental group 2- Mice were administered cadmium chloride at a dose of $50 \mathrm{mg} / \mathrm{kg} / \mathrm{animal} / \mathrm{day}$ for a day. Group experimental group 3 - Mice were administered curcumin (10mg/animal/day) for 15 days and on the 16th day cadmium chloride $(50 \mathrm{mg} / \mathrm{kg} / \mathrm{animal} /$ day) were administered.

24 hours after administration of last dose, the control and the experimental animals were sacrificed by cervical dislocation and lungs were surgically removed.

\section{Histological preparation:-}

Surgically removed lungs were fixed in Bouins solution for 24 hours and subsequently processed for parafin wax block preparation as per the technique of Drury and Wallington (1967). Sections, 5-7 $\mu$ in thickness were cut with a rotary microtome subsequently deparaffinized in xylene. The deparaffinized sections were stained with haematoxylin and eosin stains( $\mathrm{H}$ and $\mathrm{E})$. Appropriate sections were observed under the microscope and photographed.

\section{Histochemical method:-}

Lungs were fixed in chilled calcium formol $\left(4^{0} \mathrm{C}\right)$ and kept in a refrigerator, for $18-20 \mathrm{~h}$ and were further processed for localization of LDH as per the technique of Hess et al. (1958).

\section{Biochemical estimation:-}

A $10 \%(\mathrm{w} / \mathrm{v})$ homogenate of lungs was prepared in ice-cold phosphate buffer (pH 7.4) using a chilled glass-teflon porter tissue grinder tube, and then centrifuged at $3000 \mathrm{rpm}$ for $15 \mathrm{~min}$. The supernatant was used for estimation of LDH. LDH levels were estimated by using kits supplied by Span Diagnostics. Statistical Analysis: The values were 
represented as mean \pm SEM at $n=6$ experiments. The values were taken as significant at $\mathrm{P}<0.05$ ANOVA (analysis of variance).

\section{Results:-}

Histopathological profile of lungs:-

The animals in control and curcumin treated groups lung, showed no signs of gross toxicity.Normal alveoli were observed to be composed of single layer of epithelial cells and intermittent thin layered connective tissue and capillaries lined with simple epithelium were distinctly visible, (Fig.1-2) Administration of cadmium $(50 \mathrm{mg} / \mathrm{kg} / \mathrm{animal} / \mathrm{day})$ treated lungs showed altered histopathology with a profound deterioration in histopathology of alveoli as, manifested by thickening of interalveolar septa, aggregation of lymphocyte infiltration, oedema (Fig.3).In the experimental group animals, pretreated with curcumin (10mg/animal/day) histopathology of lungs showed reduced damage as manifested by lack ofoedema, aggregation of lymphocyte was not evident and thin interalveolar septas were similar to the control group (Fig.4).

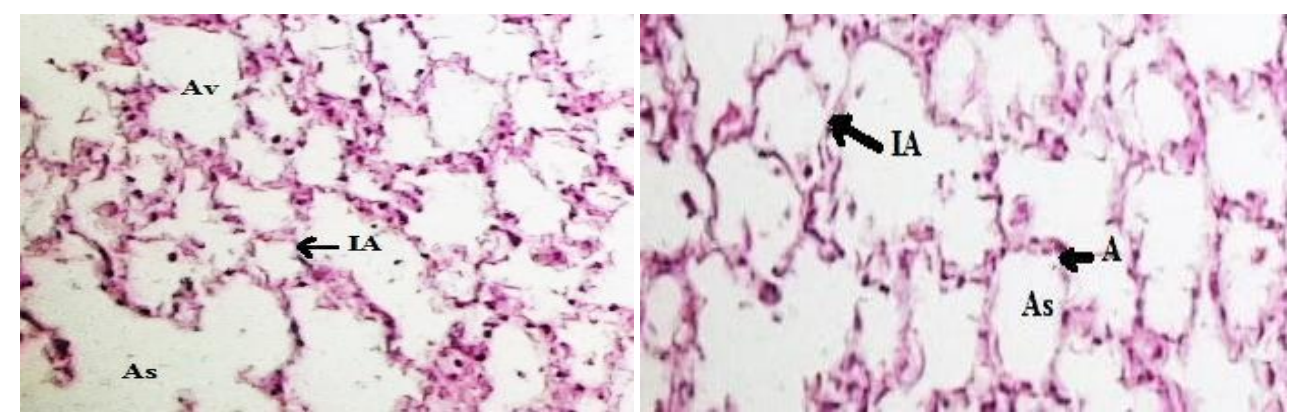

Fig.1:-

Fig.2:-

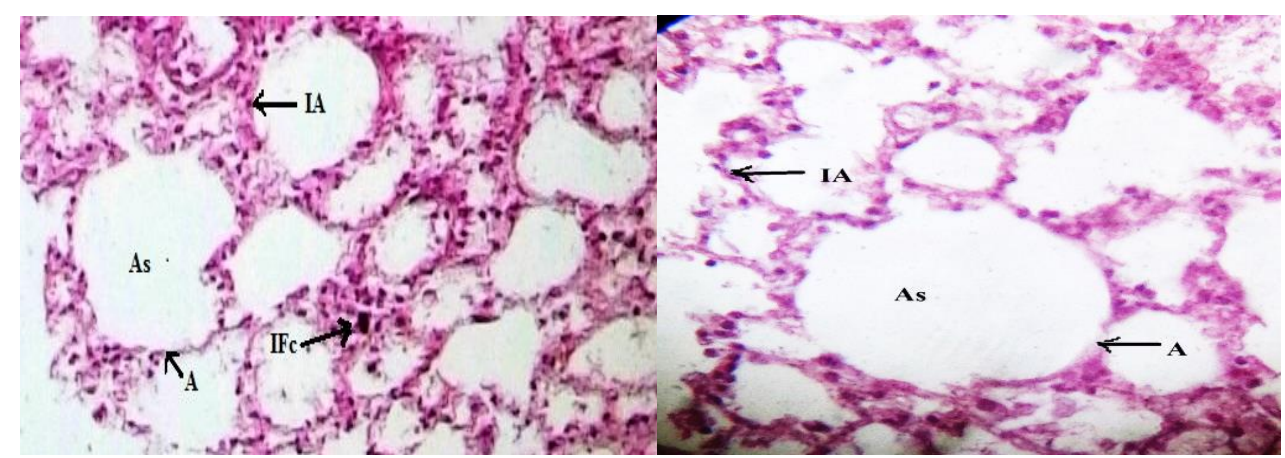

Fig.3:-

Fig.4:-

Fig.1:Photomicrograph showingT.S. of lung(stained with $\mathrm{H}$ and $\mathrm{E}$ ) of control group administered only vehicle. Alveoli (Av), alveolar space (As), interalveolar septa (IA) are visible.(10X)

Fig.2: Photomicrograph showing T.S.of lung (stained with $\mathrm{H}$ and E)of curcumin treated group mice. Alveoli (A), alveolar space (As), interalveolar septa (IA) are seen similar to control group. (10X)

Fig.3: Photomicrograph showing T.S.of lung(stained with $\mathrm{H}$ and $\mathrm{E}$ ) of $\mathrm{CdCl}_{2}$ treated group mice. Thickening of interalveolar septa (IA), aggregation of lymphocyte infiltration (IFc),oedema are visible. (10X)

Fig.4: Photomicrographshowing T.S.of lung(stained with $\mathrm{H}$ and E)curcumin pretreated group mice. Cadmium treated acute deterioration was protected. (20X)

Histochemical profile of LDH in lungs(Table I and Fig5):-

The localization of lactate dehydrogenase enzyme (LDH) was different in the lung tissue components of control, curcumin and cadmium treated groups. The bronchial epithelia, endothelia and interlobular areas of control group animals showed strong LDH activity. Bronchial and vascular muscles and free alveolar walls showed moderate enzyme activities. Light activity of enzyme was also seen in free alveolar macrophages of control group but in curcumin treated groups it was negligible (Fig.5a). 
Cadmium chloride $(50 \mathrm{mg} / \mathrm{kg} /$ animal for a day) treated group showed differential LDH reaction in various lung tissue as compared to control. Bronchial epithelia, endothelia and interlobular areas showed very strong enzymatic activity and strong activity in bronchial and vascular muscles and free alveolar walls. Free alveolar macrophages showed moderate activity in treated groups (Fig.5 b).

Curcumin pretreated group displayed light reactions of LDH activity in comparison to cadmium treated group. Bronchial epithelia, alveolar walls and interlobular areas presented moderate and strong in endothelia region. The enzyme was light in bronchial and vascular muscles and absent in free alveolar macrophages as shown in (Fig.5c).

Table I:- Protective effect of curcumin against cadmium chloride induced elevated LDH Activity.

\begin{tabular}{|l|l|l|l|l|l|l|l|}
\hline Dose & $\begin{array}{l}\text { Bronchial } \\
\text { epithelia }\end{array}$ & $\begin{array}{l}\text { Bronchial } \\
\text { and vascular } \\
\text { muscles }\end{array}$ & $\begin{array}{l}\text { Alveolar } \\
\text { walls }\end{array}$ & $\begin{array}{l}\text { Free alveolar } \\
\text { macrophages }\end{array}$ & Endothelia & Interlobular areas \\
\hline Control & +++ & & ++ & ++ & + & +++ & +++ \\
\hline $\mathrm{Cur}$ & +++ & & ++ & ++ & - & +++ & ++ \\
\hline $\mathrm{CdCl}_{2}$ & ++++ & & +++ & +++ & ++ & ++++ & ++++ \\
\hline $\mathrm{Cur}+\mathrm{CdCl}_{2}$ & ++ & & + & ++ & - & +++ & ++ \\
\hline
\end{tabular}

Histoenzymological index taken for enzymatic activity was as follows: ++++ (very strong $)>+++($ strong $)>++$ (moderate) $>+$ (light) $>$ - (no activity)

Fig.5:- Histochemical Localization of LDH Activity in Lungs of Swiss Albino Mice.

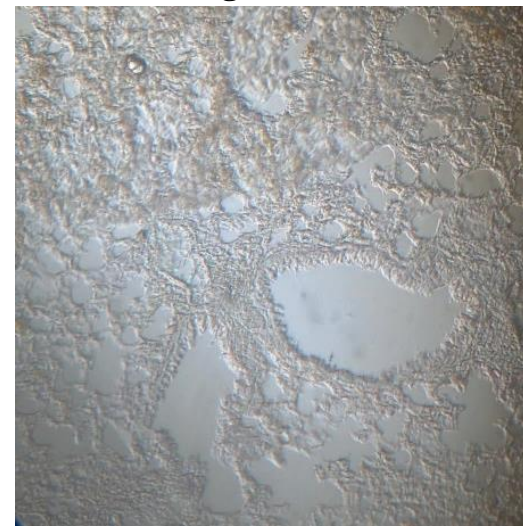

(a)

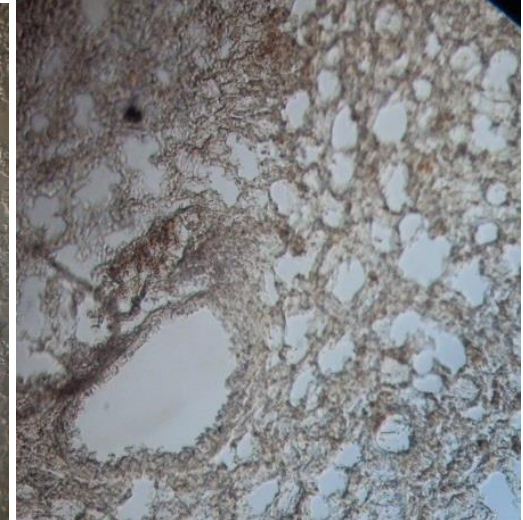

(b)

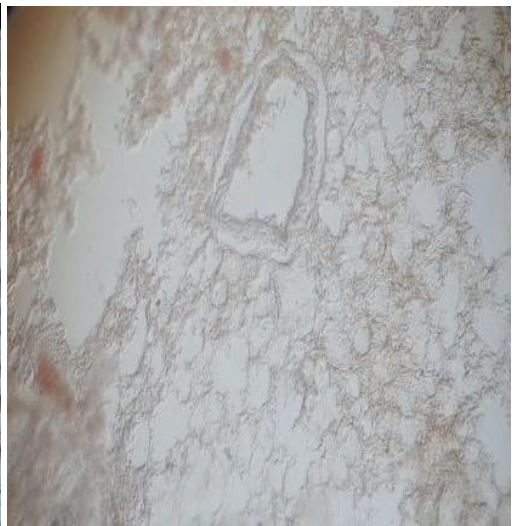

(c)

(a) T.S. of control group lung (10X); (b) T.S. of $\mathrm{CdCl}_{2}$ treated group lung (10X); (c) T.S. of Curcumin pretreated group lung (10X)

\section{Biochemical profile of LDH in lungs:-}

The biochemical results of LDH activity in lungs are presented in Table II and Fig.6. The estimates of LDH activity ${ }_{1}$ in lungs calculate according to the following formula: $\mathrm{LDH}(\mathrm{U} / \mathrm{L})=(\Delta \mathrm{Abs} / \mathrm{min}) \mathrm{x}$ factor, $\varepsilon_{\mathrm{NAD} / \mathrm{NADH}}=6230 \mathrm{M}^{-1} \mathrm{~cm}^{-}$

LDH activity in cadmium treated group was significantly elevated than the activity in the control group lungs (p < 0.05). However an extremely significant decrease in LDH activity in pretreated with curcumin groups when compared with cadmium treated groups and nearly equal to control group was observed (Fig.6, Table II).

TableII:- Quantitative Estimation of LDH (U/L) in Lungs of Swiss Albino Mice Administered Curcumin and Cadmium Chloride.

\begin{tabular}{|l|l|l|}
\hline S.No. & Dose protocol & LDH estimates (Mean \pm SEM ) \\
\hline 1 & Control & $2854.5 \pm 1.817$ \\
\hline 2 & Curcumin $(10 \mathrm{mg} /$ animal/day) & $2851.667 \pm 1.851$ \\
\hline 3 & $\mathrm{CdCl}_{2}$ & $4364.333 \pm 1.833^{*}$ \\
\hline 4 & Cur cumin $+\mathrm{CdCl}_{2}$ & $2844.333 \pm 1.621^{*, * *}$ \\
\hline
\end{tabular}


Values are Means \pm SEM of 6 animals for each group. Values bearing superscript are significantly different by ANOVA at $\mathrm{p} \leq 0.05$. *: when compared different groups with control group; **: when compared $\left(\mathrm{cur}+\mathrm{CdCl}_{2}\right)$ with cadmium chloride group.

Fig.6:- Quantitative Estimation of LDH (U/L) in Lungs of Swiss Albino Mice Administered Cadmium Chloride and Curcumin.

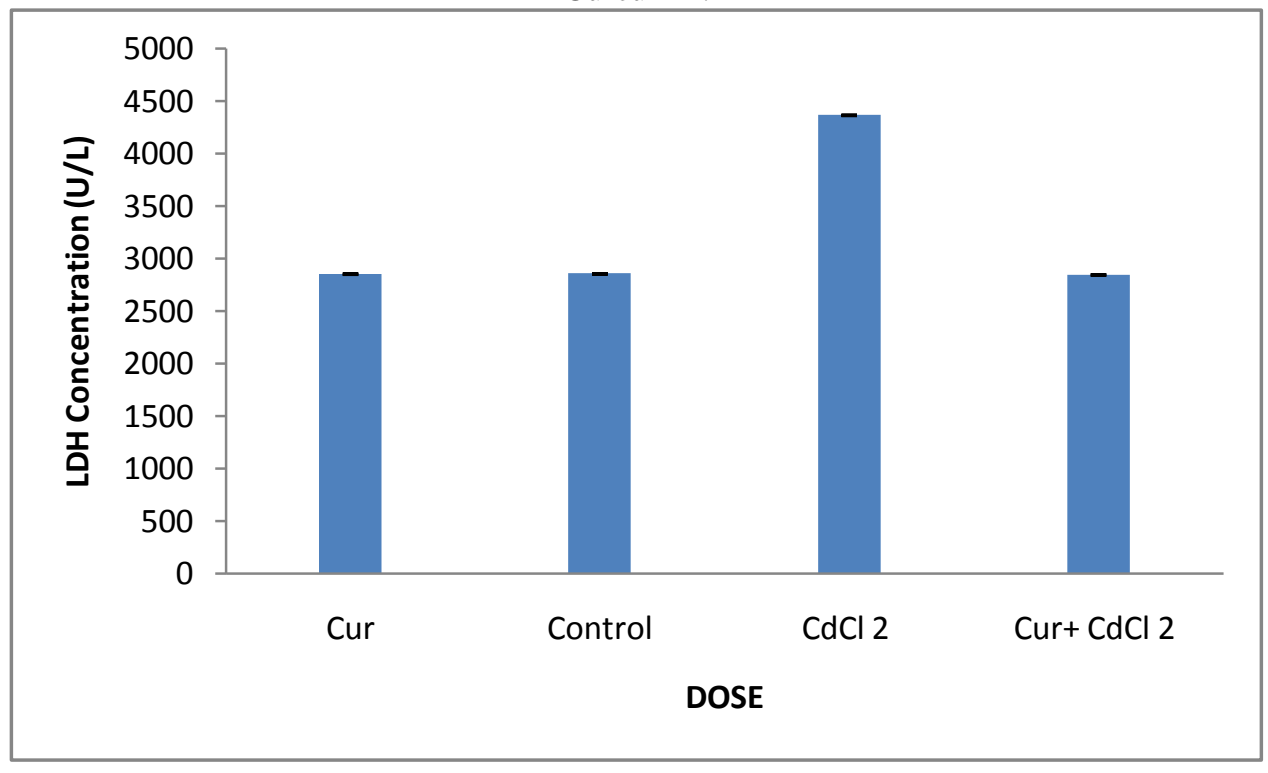

$\mathrm{CdCl} 2=$ Cadmium chloride, $\mathrm{Cur}=\mathrm{Curcumin}$

\section{Discussion:-}

It has been shown by numerous prior studies that cadmium causes pulmonary toxicity when the mode of exposure was by inhalation route especially by cigratte smoking, resulting in various lung related diseases and disorder (Lag et al. 2010). However the reports of cadmium ingested by oral route resulting in pulmonary distress are scarce and in the present research an effort has been made to assess the damage caused by cadmium and protection rendered by curcumin. In the present study the lungs of animals treated with cadmium $(50 \mathrm{mg} / \mathrm{kg} / \mathrm{animal} /$ day $)$ showed profound deterioration in histopathology of alveoli as, manifested by thickening of interalveolar septa, aggregation of lymphocyte infiltration, oedema etc.

A number of reports corroborate the results of the present study, where Damiano et al (1990) showed lung injury induced by intratracheal instillation of cadmium chloride ( $400 \mu \mathrm{g}$ or $50 \mu$ gmeach in $400 \mu \mathrm{l}$ of neutral saline). He observed cadmium induced morphological changes viz. the presence of inflammatory cells in the alveolar interstitium, oedema and alveolar wall thickening.

It has been shown that cadmium content of cigarettes is much lower than that of food; however cadmium was found to be absorbed much more effectively by the lung than the gut. Stinn et al. (2013) in his study investigated the effects of cigarette mainstream smoke exposure to male mice (6/day, 5 days/week at 150 and 300mg total particulate matter per cubic meter). He observed nodular hyperplasia of the alveolar epithelium, bronchioloalveolar adenoma and adenocarcinoma. After 18 months of cigarette smoke inhalation there was formation of lung tumors.

Blum et al. (2014) demonstrated that short term inhalation exposure to cadmium oxide nano particles stimulated the pathway associated with inflammation, cell injury, and tissue remodeling in the lungs as well as altered the immune function.

Enzyme levels of LDH have been determined by Moss et al. in 1986 , in various tissues (in U.g-1 wet weight) and were very high as compared to those in serum, liver 9,000; heart 25,000; kidney 15,000; skeletal muscle 9,000; lung 9,500. Thus it is indicated that tissue levels of LDH were about 500 fold higher than those normally found in serum, 
and leakage of the enzyme from even a small mass of damaged tissue could increase the observed serum level of LDH to a significant extent. Thus elevated levels of LDH in tissue serves as an indicative of related tissue damage.

In a similar study, Drentet al. (1996), reported cytoplasmic cellular enzyme, LDH, to be present in the extracellular space, having no further metabolic function in that space, was still of benefit because it served as indicators, suggestive of disturbed cellular integrity induced by pathological conditions. LDH enzyme has been present essentially in all major organ systems and its serum activity has been reported to be abnormal in a large number of disorders. Extracellular appearance of LDH has been used to detect cell damage or cell death. Its release has been found into the peripheral blood after cell death caused by, e.g. ischemia, excess heat or cold, starvation, dehydration, injury, exposure to bacterial toxins, after ingestion of certain drugs, and from chemical poisonings. Measurement of LDH and LDH isoenzymes in pleural fluid, and in bronchoalveolar lavage (BAL) fluid, has been reported to be useful to determine lung tissue damage and pulmonary endothelial cell injury. If cell lysis occurred, or cell membranes have damaged, cytoplasmic enzymes, such as LDH and glutathione reductase (GR), had released into the extracellular space. Activity of LDH had been reported to be present in almost all cells of the body.

In the present study it was observed that in cadmium treated experimental group the quantitative estimates of LDH appeared to be significantly elevated indicating pulmonary stress and damage. These observations are similar to the observations of Gaultet al. (1967) who reported the elevated serum levels of (LDH), in 30 patients which were diagnosed as primary and four with secondary neoplasms of the lung.

Henderson et al. (1979), found a predominantly interstitial reaction rather than an exudative one, with mononuclear phagocytes and lymphocytes rather than polymorphonuclear leukocytes (PMNs) being the predominant inflammatory cell types after inhalation of toxicant cadmium chloride inducing pulmonary injury in hamsters. Tissue morphological changes correlated well with the biochemical changes. The elevated LDH tissue levels remained for more than 3 weeks after exposure, suggesting some residual sub-acute inflammation. Airway enzymatic and cytological responses were showed to be potentially useful as indicators of lung damage in toxicological screening, as well as screening of lung injury of unknown origin.

In vitro studies done by Lott etal. 1987 demonstrated LDH leakage from type II pneumocytes, pulmonary endothelium and AMs following cellular damage caused by various stimuli. Injury to the basolateral aspect of endothelial cells was supposed to release LDH into the alveolar interstitium, and thus a compromised alveolar epithelial barrier allowed access of the enzyme into alveolar spaces. Mechanisms for increased levels of enzymes in the lavage fluid were considered to reflect cell damage, increased production and release from cells, and impaired catabolism. Thus, LDH might be released from injured cells of the lung into the pulmonary interstitium and alveoli, or from damaged inflammatory cells that infiltrated the lung after treatment.

When homogenates of human pulmonary tissue were assayed for LDH, a particular and identifying isoenzyme pattern was found. Analysis of lung washing as a probe to detect early responses of the lung has been used to access LDH activity in the airways of rats to detect the effect of a toxicant in the lung. Moreover, in animal models, LDH isoenzyme patterns have been used to differentiate between various types of pulmonary injury and have helped to identify the sites of injury at a cellular level (Beck et al.1983).

Tzouvelekiset al. (2005) reported that in addition of the activity and release of a large body of inflammatory mediators including tumor necrosis factor (TNF), antioxidant enzymes (glutathione), procollagen peptides (type III) and markers of cell damage such as lactate dehydrogenase (LDH) have been evaluated as prognostic and monitoring tools of the disease development, activity and progression.

To fulfill the need of useful biomarkers to monitor hazardous coal exposure effects on lungs. Cobbenet al. (1997) studied the role of LDH (a marker of cell damage) as marker of lung tissue injury. Authors conducted the first human study describing a considerable elevation of this enzyme in a group of ex-coalminers and a further association with other clinical variables. Additionally, the same group of investigators evaluated the role of bglucuronidase as marker of phagocytic activity and reported increased plasma concentrations in a group of coalminers after 20 years of exposure whereas no correlation with clinical parameters was observed. The latter data is in line with the hypothesis that LDH and b-glucuronidase activity are conceivable markers of disease activity (Cobbenet al. 1999; Tzouvelekiset al. 2005). 
In the present study pretreatment with curcumin to cadmium treated organisms displayed, the histoenzymological reactions of LDH activity in comparison to cadmium treated group was declined. Bronchial epithelia, alveolar walls and interlobular areas presented moderate and strong activity in endothelia region. The enzyme activity was light in bronchial and vascular muscles and absent in free alveolar macrophages.

In the present experimental group animals, pretreated with curcumin $(10 \mathrm{mg} / \mathrm{animal} / \mathrm{day})$ histopathology of lungs showed reduced damage as manifested by no oedema, aggregation of lymphocyte was not evident and thin interalveolar septas were similar to the control group.

The study of Venkatesan (1999) assessed the toxicity of paraquat (PQ) and therapeutic efficacy of curcumin.He observed the influx of inflammatory cells, releasing proteolytic enzymes and oxygen free radicals which destroyed the lung epithelium and resulted in pulmonary fibrosis. This observation is similar to the results of the present study. Curcumin was confirmed to be endowed with the therapeutic potency against paraquat lung injury. These findings indicated that curcumin has important therapeutic implications which are also indicated in the present study.

Punithavathiet al. (2003) reported the potential of curcumin to prevent lung fibrosis induced by amiodarone in rats where intratracheal instillation of amiodarone $(6.25 \mathrm{mg} / \mathrm{kg}$ on days 0 and 2 , and then killed on day 3 , day 5 , week 1 , week 3 and week 5 after amiodarone administration) induced increases in total protein and lactate dehydrogenase (LDH) activity on days 3 and 5 in bronchoalveolar lavage fluid (BALF). Total cell counts, alveolar macrophages, neutrophils and eosinophils recovered by BAL, and lung myeloperoxidase (MPO) activity were also found higher in amiodarone treated rats than in controls. Curcumin $(200 \mathrm{mg} / \mathrm{kg}$ body weight after first amiodarone instillation and daily thereafter for 5 weeks)-treated amiodarone rats had reduced levels of protein, LDH activity, total cell numbers and differential cell counts in BALF. Curcumin inhibited the increases in lung MPO activity and had proved important implications for the treatment of amiodarone-induced lung fibrosis. These observations are also similar to the findings of the present study where pretreatment with curcumin for fifteen days had considerable potency to prevent cadmium induced pulmonary stress.

Venkatesanet al. (2007) reported the therapeutic healing potential of curcumin in acute and chronic lung injuries induced by occupational and environmental exposures to mineral dusts, airborne pollutants, and cigarette smoke.

\section{Conclusion:-}

Present study distinctly demonstrates that a single oral dose of cadmium chloride can stimulate pathways in the lungs associated with inflammation, cell injury, and interalveolar septal thickening leading to pulmonary stress whereas pretreatment with curcumin prior to cadmium exposure has the potency to render protection against deleterious pulmonary effects.

\section{References:-}

1. Agency for Toxic Substances and Disease Registry (ATSDR) (2012): Toxicological profile for cadmium. Public Health Service, U.S. Department of Health and Human Services.Atlanta, GA.

2. Aggarwal, B. and Shishodia, S. (2006): Molecular targets of dietary agents for prevention and therapy of cancer. Biochem. Pharmacol, 71:1397-1421.

3. Asai, A. and Miyazawa, T. (2001): Dietary curcuminoids prevent high-fat diet-induced lipid accumulation in rat liver and epididymal adipose tissue. J. Nutr., 131: 2932-5.

4. Beck, B.D., Gerson, B., Feldman, H.A., Brain, J.D. (1983): Lactate dehydrogenase isoenzymes in hamster lung lavage fluid after lung injury. Toxicol. Appl. Pharmacol., 71: 59-71.

5. Blum, J.L., Rosenblum, L.K.., Grunig, G., Beasley M.B., Xiong J.Q. and Zelikoff J.T. (2014): Short -term inhalation of cadmium oxide nanoparticles alters pulmonary dynamics associated with lung injury, inflammation, and repair in a mouse model. Inhal. Toxicol., 26(1):48-58.

6. Cobben, N.A., Jacobs, J.A., Visser, M.P., Mulder, P.G.H., Wouters, E.F.M. Drent, M. (1999): Diagnostic value of BAL fluid cellular profile and enzymes in infectious pulmonary disorders. Eur. Respir. J., 14:496-502.

7. Coben, N.A., Drent, M., Schols, A.M., Lamers, R.J., Wouters, E.F., Van, M.P. (1997): Serum lactate dehydrogenase and its isoenzyme pattern in ex-coalminers. Respir. Med., 91(10):616-23.

8. Damiano, V.V., Cherian, P.V., Frankel, F.R., Steeger, T.J.R., Sohn, M., Oppenheim DandWeinbaum, G. (1990): Intraluminal fibrosis induced unilaterally by lobar instillation of $\mathrm{CdCl} 2$ into the rat lung. Amer. J. Pathol. 137(4). 
9. Drent, M., Cobben, N.A.M., Henderson, R.F., Wouters, E.F.M., Dieijen-Visser, M. (1996): Usefulness of lactate dehydrogenase and its isoenzymes as indicators of lung damage or inflammation. Eur. Respir. J., 9:1736-1742.

10. Drury, R. A. B. and Wallington, E.A. (1967): Carletons histological technique. $4^{\text {th }}$ edition book.

11. Gault, M.H., Cohen, M.W., Kahana, L.M., Leelin, F.T., Meakins, J.F and Aronovitch, M. (1967): Serum enzymes in patients with carcinoma of lung, Lactic-Acid Dehydrogenase, PhosphohexoseIsomerase, Alkaline Phosphatase and Glutamic Oxaloacetic Transaminase. Can. Med. Assoc. J., 96(2): 87-94.

12. Henderson, R.F., Rebar, A.H., Pickrell, J.A., Newton, G.J. (1979): Early damage indicators in the lung. III. Biochemical and cytological response of the lung to inhaled metal salts. Toxicol. Appl. Pharmacol., 50: 123136.

13. Hess, R., Scarpelli, D.G. and Pearse, A.G.E. (1958): The Cytochemical Localization of Oxidative Enzymes II. Pyridine Nucleotide-Linked Dehydrogenases,JCB., 4(6):753-760.

14. Lag, M., Rodinov, D., Orevik, J., Bakke, O., Schwarze, P.E., Refsnes, M. (2010): Cadmium -induced inflammatory responses in cells relevant for lung toxicity: Exppression and release of cytokines in fibroblasts, epithelial cells and macrophages. Toxicol. Letter., 193(3):252-260.

15. Lott, J.A., Nemensanszky, E. (1987): Lactate dehydrogenase. In: Lott JA, Wolf PL, eds. Clinical Enzymology, a Caseoriented Approach., 213-244.

16. Moss, D.W., Henderson, A.R. (1986): Enzymes. In: Burtis CA, Ashwood ER, eds. Tietz Textbook of Clinical Chemistry.2nd edn. Philadelphia, Saunders Co., 735-896.

17. Naksuriya, O., Okonogi, S., Schiffelers, R.M. and Hennink, W.E. (2014): Curcumin nano formulations: a review of pharmaceutical properties and preclinical studies and clinical data related to cancer treatment. Biomat.35(10):3365-83.

18. Nordberg, G. F. and Kjellström, T. (1979): Metabolic Model for Cadmium in or inflammation. Man. Environ. Health. Persp.,28:211-217.

19. Pandey, A., Dwivedi, V. and Mishra, K. (2010): Drug Sensitivity of curcumin analogues and conjugates. Bio. Active. Nat. Prod., 7:267-298.

20. Phan, T.T., See, P, Lee ST and Chan SY (2001): Protective effects of curcumin against oxidative damage on skin cells in vitro: its implication for wound healing. J Trauma, 51: 927-31.

21. Punithavathi, D., VenkatesanNandBabu, M. (2003) Protective effects of curcumin against amiodarone-induced pulmonary fibrosis in rats. British. J. Pharmacol., 139, 1342-1350.

22. Sharma, R. A., Gescher, A. J. and Steward, W. P. (2005): Curcumin: the story so far. Eur. J. Cancer., 41(13):1955-68.

23. Shahed, A.R., Jones, E. and Shoskes, D. (2001): Quercetin and curcumin upregulate antioxidant gene expression in rat kidney after ureteral obstruction or ischemia/reperfusion injury. Transplant. Proc,33:2988.

24. Singh, P. and Mogra, P. (2010): Beneficial effects of curcumin on cadmium chloride induced decline in food intake and general wellbeing in Swiss albino mice. Aishwarya research communication, 1(2):132-137.

25. Singh, P., Chaudhary, S., Patni, A., Sankhla, V. (2007): Effect of cadmium chloride induced genotoxicity in bone marrow chromosomes of swiss albino mice and subsequent protective effects of Emblicaofficinalis and vitamin C. J. of Herbal Med. and Toxicology,1 (2) :67-71.

26. Singh, P., and Sankhla, V., (2010): In situ protective effect of curcumin on cadmium chloride induced genotoxicity in bone marrow chromosomes of Swiss albino mice. J. of cell and mol. biol, Turkey, 8(2): 57-64.

27. Singh, P., Deora, K., Banu, H., Mogra, P., Javeria,S. and Barolia,S., (2012): Protective effect of curcumin on cadmium chloride induced epididymal toxicity in swiss mice (Musmusculus), J. Chem. Bio. Phy. Sci. Sec.B,2(2):797-805.

28. Singh, P., Mogra, P., Sankhla, V., and Deora, K., (2011): Protective effect of curcumin on cadmium chloride induced colon toxicity in Swiss albino mice. J. cell and mol.biol.,9 (1):31-36.

29. Singh, P., Mogra, P., and Sankhla, V., Deora, K., and Patni, A. (2010): Esophageal mucoprotective effects of curcumin on cadmium chloride induced toxicity in Swiss albino mice. Folk herbal medicine and drug discovery, 15:181-188.

30. Singh, P., and Sankhla, V., Mogra, P., and Patni, A. (2010): Protective effect of curcumin on cadmium chloride induced nephrotoxicity in Swiss albino mice. J. Herbal Medicine and Toxicol.,4(2): 215-219.

31. Singh, S. and Khar, A. (2006): Biological effects of curcumin and its role in cancer chemoprevention and therapy. Anticancer Agents Med. Chem. 6(3):259-270.

32. Soni, K.B. and Kuttan, R. (1992): Effect of oral curcumin administration on serum peroxides and cholesterol levels in human volunteers. Indian J. Physiol. Pharmacol., 36: 273-275. 
33. Stinn, W., Buettner, A., Weiler, H., Friedrichs, B., Luetjen, S., Overveld, F.V., Meurrens, K., Janssens, K., Gebel, S., Stabbert, R. and Haussmann, H. Lung Inflammatory effects, tumorigenesis, and emphysema development in a long-term inhalation study with cigarette mainstream smoke in mice. Toxicol Sci.131 (2): 596-611, 2013.

34. Tzouvelekis, A., Kouliatsis, G., Anevlavis, S. and Bouros, D. (2005): Serum biomarkers in interstitial lung diseases. Respiratory Research.,6:78.

35. Venkatesan, N., Punithavathi, D., Babu, M. (2007) Protection from acute and chronic lung diseases by curcumin. Adv. Exp. Med. Biol., 595:379-405.

36. Venkatesan, N. (1999): Pulmonary protective effects of curcumin against paraquat toxicity. Life Sciences.,66( 2) : 21-28.

37. Venkatesan, N., Punithavathi, V. and Chandrakasan, G. (1997): Curcumin protects bleomycin-induced lung injury in rats. Life Sci, 61: 51-58.

38. Xu, Y. M., Wu, D. D., Lau, A.T.Y. (2015): Proteome profiing of cadmium-induced apoptosis by antibody arry analysis in human bronhioal epithelial cells. Onco. Target., 7:5.

39. Zhang, D., Fu, M., Gao, S. and Liu, J. (2013): Curcumin and Diabetes: A Systematic Review. Evidence-Based Complementary and Alternative Medicine., 2013:16. 